\title{
Mística e corporeidade: experiência, ética e práxis em Simone Weil
}

\author{
Orientadora: Maria Clara Lucchetti Bingemer \\ Doutoranda: Andreia Cristina Serrato \\ Área de Concentração: Teologia Sistemático-Pastoral \\ Linha de Pesquisa: Religião e Modernidade
}

Mística e corporeidade: experiência, ética e práxis em Simone Weil caracteriza-se por um trabalho de pesquisa que se desenvolve a partir da experiência mística corpórea da filósofa de Paris, Simone Weil, que viveu uma experiência práxis místico-ética unitária em seu corpo e alma. Essa experiência se intensificou ao "sentir-se tomada por Cristo" em sua própria carne. Demonstraremos essa experiência a partir de sua linguagem místico-erótica, que a faz entregar-se inteiramente ao Outro. Sua espera (en attente) pelo encontro com Deus, ou melhor, ser encontrada por Ele, permite uma vida de configuração ao corpo de Cristo, a partir da proximidade com a ética Paulina, solidarizando-se em sua própria carne com as "dores da humanidade", assim como Cristo, que entregou seu corpo para todos, culminando na verdadeira experiência eucarística: dar-se em comida e bebida para os demais. De início, nosso estudo fundamenta-se em diversas áreas do saber como sociologia, psicologia e filosofia para discorrermos sobre a temática do corpo na contemporaneidade. Terá seu porto seguro na teologia. Em seguida, nossa reflexão será realizada à luz da experiência de Simone Weil. Identificamos essa experiência mística em duas linhas de reflexão. A primeira "O corpo que sofre, incontinente e resistente"; e a segunda, "O corpo que ama, como sensibilidade para amar e vibrar". No último passo apresentaremos sinais de uma mística erótica apostólica de configuração ao corpo do Cristo a partir de Simone Weil que aponte caminhos para se viver a mística hoje.

Palavras-chave: Simone Weil. Corpo. Mística. Experiência. 